ISSN: 2036-5438

\title{
Monetary and Fiscal Arrangements for the Eurozone: Some Unconventional Proposals
}

by

\author{
Fabio Masini*
}

Perspectives on Federalism, Vol. 8, issue 2, 2016 


\begin{abstract}
Contributions in this special issue argue make a number of points with regard to the urgent need to change the economic governance of the Eurozone, pointing at some tools to increase its spending capacity. The process of potential fragmentation ignited by the recent vote on Brexit make such changes even more urgent, signalling the need to provide concrete responses to citizens, in order to show that the euro area, and the EU at large, are able to satisfy some of their crucial needs. The papers which make up this special issue were presented in Florence, at a meeting held in the framework of a Jean Monnet + Project called MoreEU. The first section deals with the reform of the budget; the second with a further use of quantitative easing and the role of the ECB.
\end{abstract}

Key-words

Eurozone, economic governance, European Central Bank, Brexit crisis 


\section{Introduction}

The US financial crisis, which started in 2007, precipitated a euro sovereign-debt crisis from 2010. The generalized credit crunch, followed by unprecedented, and concerted, liquidity injections via both fiscal and monetary impulses, created an enormous amount of financial resources in the world, waiting for remunerative opportunities for speculation. The Greek crisis, ignited by the recognition of fake budgetary reports to the EU Commission, gave financial markets a spectacular chance of investment. Speculation attacks vulnerable systems; and currently the most vulnerable economic system in the world is the euro-area, where monetary authority is completely detached from any other economic policy tool. Domino effects soon affected the PIIGS, thus igniting a euro-area sovereign-debt crisis that is still unresolved. The ECB took up the responsibility to halt speculation, flooding the market with euros. But the intrinsic shortcomings of Eurozone governance transformed monetary easing into a liquidity trap.

Since the start of the crisis, asymmetries among euro countries have grown deeper, making it more and more urgent to effectively tackle EU-specific critical features. The euro crisis is endogenous to EU economic and political governance, and thus requires a dramatic change in its operating mechanisms. Economic policy is a complex system of objectives and tools that have to be appropriately coordinated in order to be effective. The coordinating system adopted at the euro level is not only insufficient, but actually so perverse that negative effects are the most likely result of any action. In this (nation-centred stabilization policy) framework, fiscal consolidation and expansionary austerity (Alesina, Ardagna 2009) were the only viable strategies that could be adopted, hoping they might work. Unfortunately, they did not. Each and every contribution in the following pages acknowledges the urgent need to change the economic governance of the Eurozone, pointing at some tools to increase its spending capacity. The process of potential fragmentation ignited by the recent vote on Brexit make such changes even more urgent, signalling the need to provide concrete responses to citizens, in order to show that the euro area, and the EU at large, are able to satisfy some of their crucial needs. Although any turmoil following this event had not yet happened when the following papers were 
presented in Florence, at a meeting held in the framework of a Jean Monnet + Project called MoreEU, we think they can provide food for thought and action in the next months. We will briefly discuss them in the following sections, trying to address the main issues they raise. The first section deals with the reform of the budget; the second with a further use of quantitative easing and the role of the ECB.

\section{From the MFF negotiations to a Eurozone Budget}

An important area of change concerns the budget. As it is well known, the Treaties require that the EU budget balance and changing this provision requires unanimity in the Council. Nevertheless, there are many interesting points on which a reform of the EU budget can be looked at. The first is radical, and concerns the creation of a separate budget for the Eurozone, within an enhanced cooperation, that may be able to collect its own resources, issue project bonds, and decide the allocation of financial resources to the provision of specific (and well defined) collective goods. Both the economic literature (Haug et al. 2011) and EU institutions (High Level Group on Own Resources 2014; European Parliament 2016) have recognized the need to enhance the budgetary capacity of the EU. Only politicians seem to be reluctant to make any step further on this.

Although the debate concerning the proper dimension of the budget, dating back to the Seventies (MacDougall 1977), crucially depends on the attributions given to the supranational institutions, there are a couple of general reflections worth underlining. As suggested by the first report of the Monti Group: "reforming the system presents a formidable challenge" (High Level Group on Own Resources 2014, 7), the major problems stems from the collection system, still mainly organized on a national basis: "own resources are not 'genuine' for the most part but de facto national contributions. This criticism reflects the fact that around $83 \%$ of the Union's revenue come directly from the national budgets" (ibid. 13), and the report acknowledges the difficulty of any improvement: "the decision making process makes it extremely difficult to reform the system, since the 28 Member States must agree to any change.” (ibid. 14). Given this framework for institutional change, and acknowledging at the same time the urge to increase budgetary responsibility to the supranational level, there is only one possible short term solution: to create a specific 
budget for the Eurozone, or for a core of countries within the euro area that agree to step further towards integration.

These revenues should come from fiscal and borrowing capacity. As concerns fiscal capacity, this should count on its own additional resources - as already had afforded to the European Coal and Steel Community and as envisaged in the Four Presidents Report (Van Rumpuy et al. 2012) and the Five Presidents Report (Juncker et al. 2015) - such as 'federal' taxes, levied on some common evils, such as gambling, tobacco, carbon emissions, and on the financial sector. A Financial Transaction Tax, assuming no reduction in financial transactions in Europe, might not cast "sand in the wheels of international finance" (Tobin 1974; 1978), but might effectively contribute to finance the European commons. The "Commission proposed the introduction of a financial transaction tax (FTT) own resource and a new VAT resource, both from 1 January 2018 at the latest" (High Level Group on Own Resources 2014, 19). One might even think of taxes on personal income, but the whole extent and structure of the euro-area budget depends on the competencies it is assigned and these may vary according to the results of negotiations.

In this wider reflection on own resources, Cieslukovski (infra) claims that a special place should be occupied by compliance of such resources with sustainable development goals (SDGs). Although certainly not completely new (Majocchi, Missaglia 2001; Gros 2009; Majocchi 2013). it is a challenging perspective, as it addresses, and provides a bridge between, two very urgent needs: the supply of collective goods to match European citizens preferences, and the needs of a more far-sighted perspective on stability and growth.

As concerns borrowing capacity, the idea of Euro-project bonds is long-standing: as early as 1993 Delors' White Paper on Growth, Competitiveness, Employment, suggested that European-wide investments should be financed with the issue of specific Eurobonds. Occasionally, such proposals have also been made in the last two decades (e.g. Sapir 2003). It's time to reconsider these again. The technicalities of different options for Eurobonds have been widely explored (Delpla and Von Weizsäcker 2010; De Grauwe 2011; Prodi and Quadrio Curzio 2011). At least one point is worth recalling: they should be project-bonds, issued with one or more specific aims, so that potential stakeholders may monitor the return on those investments. In other words, they should not be used to reduce debt stocks (Amato, Verhofstadt 2011), so that each country bears the burden of its responsibilities. We should recall that the Lisbon Treaty requires the budget to be in balance. To make new 
debt, the current treaties would need to be changed, whereas project-bonds could be issued by the European Investment Bank (as provided for in the Juncker Plan) in order to overcome the clause concerning a balanced budget.

As concerns expenditures, if the final objective of the institutional changes is to have more effective economic governance in Europe and greater capacity to satisfy the needs of European citizens, the Eurozone budget should aim at providing Eurozone collective goods, i.e. goods that can efficiently be provided only, or more efficiently, at the supranational level. Investments in collective goods might comprise: transport, communication and energy infrastructures; higher education and research; and support to technological innovation. According to some commentators, they should also relate to a European army and a single foreign policy, therefore enhancing the EU's capacity to tackle diplomatic challenges and strategic alliances worldwide and reduce current inefficient national expenditures. The key point is that these investments should be made at the Eurozone level, so as to compensate for the intrinsically restrictive stance of policies within the euro area. While some of these investments might be attractive to private funds, and indeed, the Juncker Plan relies on private funds for some investments, the point here is nevertheless different; in order to provide some public goods it may be necessary to have more public funds, irrespective of the interest of private investors.

Summing up, a general reconsideration of the budget in the EU is crucial, as underlined by D'Alfonso (infra), in many respects and under different criteria. The key element, nevertheless, is to go beyond the mere negotiations and logic on the Multiannual Financial Framework, and take the chance of the mid-term revision to substantially change the nature of the logic on the budget, still based mainly on the balance between pros and cons for each single country (juste retour). From this point of view, the paper by Sapala (infra) addresses exactly this issue, although she might have overestimated the extent of the revision itself. Although it acknowledges the legitimacy and efficacy shortcomings of present governance in the euro area, Nicoli's contribution (infra) focuses rather on procedural aspects, although procedures, as it is in this case, may significantly impact on policymaking. He suggests the adoption of a single budgetary procedure, designed as a coordinated action at the EU level, to make the coordination mechanism enforceable. 


\section{Monetary Policy Beyond QE}

Another crucial actor in the reform of economic governance within the Eurozone is the European Central Bank. Through an increasing use of unconventional tools of monetary policy, the ECB has acquired a status similar to that of a normal central bank. Notwithstanding the constraints of its explicit mandate (from the Council) and with an extensive interpretation of its role of targeting inflation, the quantitative easing (QE) program has allowed for the survival of the euro against speculative attacks, buying some times for governments to make the necessary reforms of the economic governance of the Eurozone. However, the absence of reforms, which the MS governments have never implemented, cast some doubts on the long term sustainability of the euro.

There are two main questions here: a) whether the ECB should become de jure a lender of last resort, as De Grauwe (2013) suggests; b) whether the ECB should go further beyond the present unconventional instruments of monetary policy. As concerns the latter point, helicopter money is risky, given the inflation potential of the liquidity injection (although now deflation seems the most urgent problem); whereas fiscal stimulus via further quantitative easing to European institutions (Stiglitz et al. 2014; Varoufakis et al. 2013; Watt 2015; Wolff 2014; Bibow 2015) might be of some help, unless it undermines ECB credibility, which brings us to the former point. Credibility is a crucial asset for monetary policy, and a strict statute may provide a solid backbone on which a young central bank might build it. Nevertheless, credibility is required more urgently in difficult times; and, in such times, discretionary power is necessary not only to be effective, but also to be credible. But any change of the explicit mandate of the ECB calls for a new, ample consensus within the Council, which is hard to imagine at present.

In this debate, an interesting proposal (requiring no change of the Treaties) is put forward by Fontana and Vannuccini (infra). They suggest that the ECB should expand QE to back a fiscal stimulus of the European Commission. In line with similar proposals, and although recognizing that this is has an inflationary potential, they claim it might be a short-term solution to substitute for the lack of effective fiscal power in the Eurozone.

There is an increasing divergence between citizens' and governments' preferences, making an increasing and dangerous gap in agency. This gap reflects the different nature between the exercise of power and the exercise of sovereignty. The first represents the struggle 
aimed at acquiring, conserving and expanding (the potential) power of decision, irrespective of the satisfaction of the need of citizens (and constituency). The exercise of sovereignty means being able to satisfy collective needs of citizens. They are different in nature and may coincide only incidentally. The use of a combination of fiscal and monetary stimuli is crucial to finance the provision of such goods.

\section{Concluding Remarks}

The current crisis in Europe is endogenous - for it had its roots in the structure of its governance, with decision-making attributed to intergovernmental institutions and methods, which proved (and still prove) ineffective to tackle economic hard times. Furthermore, Europe has no means to absorb asymmetric shocks, and to finance countercyclical policies for recovery, lacking a reasonable supranational budget and given the constraints at the national level. The only resulting strategy available was expansionary austerity, in the hope that it might work. Unfortunately, it did not.

Given the endogenous nature of the present crisis, it is necessary to change the institutional structure of economic governance. The European economy needs both demand and supply side interventions that require much more than a monetary impulse (that might prove barely sufficient in times of general distrust and liquidity traps). At the very minimum, it is necessary to pool fiscal resources for collective investments.

Given the huge policy externalities within it, this can and should be done urgently in the Eurozone framework, through enhanced cooperation, providing the euro area with: the minimal institutions to tackle effectively domestic-European asymmetric shock absorption and financing growth; a more effective executive power to the Commission, with the creation of a true supranational Treasury; a more legitimate process through a greater role for the European Parliament and the use of majority vote within the Council. We have also highlighted the difficulties in selling this reform package to national governments and citizens. Given the lack of forward-looking authoritative leaders, we should rely on a more transparent communication system in Europe, and to giving greater voice to NGOs and the European Parliament. Furthermore, we should make people understand the exact nature of the crisis: a lack of effective sovereign power that can only be exercised at the European level. 
We should do our best to come as quickly and as closely as possible to these new arrangements, within existing Treaties in the short run; and struggle to make more profound and larger changes outside of them, in the longer run, via a new fundamental law that may re-write the mechanisms of civil society cohesion in Europe. It is no longer time for drafting reports and roadmaps, but to start implementing them, with a precise, rigorous and urgent time schedule. The crises hitting Europe in the last few years have opened up a window of opportunities for radical change in EU governance. Nevertheless, there is a time constraint imposed on European citizens; and time is a scarce resource. We are aware that this, at present, is an exercise in imagination. But in times of doom and lasting crisis, even imagination may turn out to be a precious asset. The proposals suggested here, though an exercise in imagination, may turn out to be precious advice.

\footnotetext{
* University of Roma Tre.
}

References

- Alesina Alberto F. and Ardagna Silvia, 2009, Large Changes in Fiscal Policy: Taxes Versus Spending, NBER Working Papers, 15438.

- Amato Giuliano and Verhofstadt Guy, 2011, 'A plan to save the euro and curb speculators', Financial Times, July 3.

- Bibow Jörg, 2015, Making the Euro Viable: The Euro Treasury Plan, Levy Institute Working Paper, 842, July.

- De Grauwe Paul, 2011, The Governance of a fragile eurozone, CEPS Working Document, 346, May.

- De Grauwe Paul, 2013, Design Failures in the Eurozone. Can they be fixed?, European Economy Economic papers, 491, April.

- $\quad$ Delpla Jacques and von Weizsäcker Jakob, 2010, The Blue Bond Proposal, Bruegel.

- $\quad$ European Parliament, 2016, Working Document on a Budgetary Capacity for the Eurozone, February 19, DT \1086613EN.doc.

- $\quad$ Gros Daniel, 2009, A border tax to protect the global environment?, Vox, CEPR's Policy Portal, Dec. 9.

- Haug Jutta, Lamassoure Alain, Verhofstadt Guy, Gros Daniel, De Grauwe Paul, Ricard-Nihoul Gaëtane and Rubio Eulalia, 2011, Europe for Growth. For a Radical Change in Financing the EU, CEPS - Notre Europe.

- $\quad$ High Level Group on Own Resources, 2014, First Assessment Report, Bruxelles, December 17.

- Juncker Jean-Claude, Tusk Donald, Dijsselbloem Jeroen, Draghi Mario and Schulz Martin, 2015, A Deeper and Fairer Economic and Monetary Union Combining stability with fairness and democratic accountability, The Five Presidents' Report, http://ec.europa.eu/priorities/economic-monetary-union/index en.htm.

- MacDougall Donald, 1977, Report of the Study Group on Public Finance in European Integration, Brussels.

- $\quad$ Majocchi Alberto, 2013, Un Piano per l'Europa. Sviluppo sostenibile e occupazione, Franco Angeli, Milano.

- Majocchi Alberto and Missaglia Marco, 2002, Environmental taxes and border tax adjustment, Societa Italiana Economia pubblica (SIEP), Working Paper, 127.

- $\quad$ Prodi Romano and Quadrio Curzio Alberto, 2011, 'EuroUnionBond per la nuova Europa', Il Sole 24 Ore, August 23. 
- $\quad$ Sapir André, 2003, An Agenda for a Growing Europe. Making the EU Economic System Deliver, Report of an Independent High-Level Study Group established on the initiative of the President of the European Commission, Brussels, July.

- Stiglitz Joseph E., Fitoussi Jean Paul., Bofinger Peter, Esping-Andersen Gøsta, Galbraith John Kenneth and Grabel Ilene, 2014, 'A Call for Policy Change in Europe', Challenge, LVII(4): 5-17.

- $\quad$ Tobin James, 1974, The New Economics One Decade Older, Princeton University Press, Princeton, NJ.

- Tobin James, 1978, 'A Proposal for Monetary Reform', Eastern Economic Journal, XXIX(4): 519-26.

- Van Rumpuy Herman, Barroso Jean Manuel, Juncker Jean-Claude and Draghi Mario (2012), Towards a Genuine Economic and Monetary Union, 5 December, http://www.consilium.europa.eu/uedocs/cms Data/docs/pressdata/en/ec/134069.pdf.

- Varoufakis Yanis, Holland Stuart, Galbraith John Kenneth, 2013, A Modest Proposal for Resolving the Eurozone Crisis. Version 4.0, https://varoufakis.files.wordpress.com/2013/07 /a-modest-proposal-forresolving-the-eurozone-crisis-version-4-0-final1.pdf.

- Watt Andrew, 2015, Quantitative easing with bite: a proposal for conditional overt monetary financing of public investment, IMK Working Paper, 148.

- Wolff Guntram B., 2015, 'Inflation expectations and global risks: the need for ECB action', Bruegel Blog Post, October. 